\title{
Multidimensional research about oleotourism attraction from the demand point of view
}

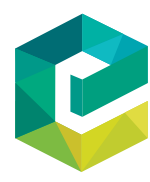

Journal of Tourism Analysis: Revista de Análisis Turístico Emerald Publishing Limited 2254-0644 2254-0644
DOI 10.1108/JTA-06-2018-0017

\author{
Ignacio Ruiz Guerra \\ Department of Business, Management and Marketing, Universidad Complutense \\ de Madrid Facultad de Comercio y Turismo, Madrid, Spain \\ Valentin Molina \\ Department of Business and Management, \\ Universidad de Granada, Granada, Spain, and \\ José Manuel Quesada \\ Department of Statistic and Operative Research, \\ Universidad de Granada, Granada, Spain
}

\begin{abstract}
Purpose - The purpose of this paper is to confirm the consumer's interests about olive oil tourism like ohter active touristic tipologies. Experimental tourism can be understood as a new trend in tourist demand. Tourists want to experiment with lifestyles in different places. The information society shows how and where the best products are cultivated and is linked to how the quality of life should be. Nowadays, we are intended to know more and better things, both tangible and intangible, and new technologies show them to us immediately. One intends to live these opportunities as soon as they can.

Design/methodology/approach - From the experimental point of view Olive Oil Tourism (Oleotourism) emerges from the olive oil consumer's interest in learning about the production process, so they can discover a lifestyle associated to this product. This research begins with an exploration of tourists' motivations. Then, focusing on these consumers, this work has different targets: first, to assess how consumers perceive intangible aspects of olive oil and, second, to forecast the potential demand for oleotourism.

Findings - The development of tourism is the result of tourist entrepreneurs that react to the pre-existing demand/opportunity by identifying it in the tourist market.

Research limitations/implications - The consumer's experience is important, but touristic trends are changing. The importance of olive oil may grow in the future because the nutrition benefits are known by all countries. The natural experience around olive oil will drive it to other stakeholders.

Practical implications - It is very early to recognize if the olive oil tourism industry is economically interesting, and whether innovative offers can be created based in olive oil and the lifestyle in rural areas.

Social implications - The local development around olive oil tourism could be a potential complement with the principal activities, which are usually agricultural activities, farmer interests and local and historical heritage. This is a means to foresee the plausible impacts of the development of oleotourism on tourist destinations, for which oleotourism might become a competitive advantage based on an agri-food product with many intangible profits: olive oil.
\end{abstract}

(C) Ignacio Ruiz Guerra, Valentin Molina and José Manuel Quesada. Published in Journal of Tourism Analysis: Revista de Análisis Turístico. Published by Emerald Publishing Limited. This article is published under the Creative Commons Attribution (CC BY 4.0) licence. Anyone may reproduce, distribute, translate and create derivative works of this article (for both commercial and noncommercial purposes), subject to full attribution to the original publication and authors. The full terms of this licence may be seen at http://creativecommons.org/licences/by/4.0/legalcode 
Originality/value - This is the first opportunity to learn about the personal interest of the consumer regarding olive oil. They give us the opportunity to know if the institutional offer about new destinations based on olive oil tourism will have a chance or will it be an economic complement with the principal activities.

Keywords Intangible benefits, Multidimensional scalling, Oleotourism, Oleotourist

Paper type Research paper

\section{Introduction}

Tourist destinations strive to enhance their resources to achieve an urban and/or rural development for new modern needs (Martha and Kotsaki, 2015). Tourism has become a way to combine past and its vestiges with an arranged exploitation according to current tastes (Molina and Ruiz, 2009; Martha and Kotsaki, 2013).

Tourists' behaviour has evolved over time, affecting not only the type and quantity of expense in their destination but also in the way one makes decisions before travelling (Mckercher and Chan, 2005; UNWTO, 2017a, 2017b).

Currently, tourists take into account the governance and best practices, not only those of the tourist providers but also those of the destinations (Dodds, Graci and Holmes, 2010). This new tourist profile contributes to improve the sustainability of the place visited, as it is done in the environment from which tourists come. The knowledge acquired in a destination is an enrichment sought by the tourist, not only because it contributes to the sustainability of the society we live in but also because it links present and past, history and future, tradition and modernity. Oleotourism gathers many of these elements, as it combines environment, culture, tradition and cuisine.

Once the tourist recognises the elements that conceptualise this new type of tourism, the Oleotourism, its demand and its study provide us with information about the tourists' motivations for having a new experience in their destinations, whereas those destinations are working to offer this kind of tourism.

The extent to which tourists recognise these elements fosters the tourist's wish to include those places in their plans, as they may appear interesting for several reasons. Among those reasons we find the experimental one. This is why in this study we will try to forecast the tourist's interest in learning about the olive oil production process.

But before addressing this possible demand, this study aimed to know if the respondents had considered olive oil potentially attractive. This is to know if an agri-food product could be acknowledged in different dimensions, so as to create an international tourist demand. Therefore, this kind of study could be extrapolated to any destination devoted to olive oil production.

As a precedent, it is important to mention the case of wine. For some time now, it has become an example of an agri-food product which has acquired a growing importance and has contributed to the tourism of wine, Enotourism. As with this kind of tourism, oleotourism seeks to combine elements that create a new model of sustainability in rural environments. New synergies of sustainable development are created, not only regarding the environment but also socio-economic ones.

The results of this study show how olive oil consumers are valuing several intangible aspects that are perceived as inherent. This even enables the assessment of the potential demand oleotourism may have according to gender, age and nationality.

\section{Tourism in Spain}

Spanish tourist destinations have diversified their offer because of the growing tourists' demand for new experiences. At the same time, academic research has focused on 
conceptualising each kind of existing tourism. In scholarly literature, many attempts to define tourists' profiles and characteristics can be found (Table I). Accordingly, the offer has tried to create tourist products which are becoming increasingly sophisticated to respond to this specific demand.

The problems in the tourist sector demand greater attention from scholars, and this field should also become a research line in itself.

Spain has achieved, in 2017, after several years of growth (UNWTO, 2017a, 2017b), the Top3 position of most visited countries by international tourists. The Spanish tourist model has worked to develop a much wider and more diverse tourist offer than the typical seasonal beach tourism (Turespaña, 2014). This is why the creation of a new tourist offer, either as a main or complementary one, through entrepreneurship, is being promoted (Tilley and Young, 2009; Parrish, 2010; Lombardi et al., 2015; Migliore et al., 2015; Caracciolo et al., 2016; Cembalo et al., 2016).

Scholarly literature has focused on the different aspects of the new offer, aiming to identify ways of sustainable growth. This is the most interesting factor in the new developments of tourist destinations (Bacq and Janssen, 2011; Migliore et al., 2014; Migliore et al., 2015; Schimmenti et al., 2016).

This research investigates the possibilities of a tourist exploitation based on olive oil. This is a markedly seasonal product because olives are only harvested in low-temperature periods, this is by the end of autumn, the beginning of winter and in markedly rural areas, where traditional olive growing is kept. During some years, there is no olive production because of the alternate bearing process (one year olives are harvested but not the following one). During the rest of the year, it can be a good complement to a main offer, for example, as an interpretation centre.

Among researchers, the most widely accepted definition for an oleotourist is the person who travels outside their residence place to get to know, in a direct way, the production process of olive oil, from the harvest of olives and the olive trees landscape, to the milling/pressing process in the mill, including a tasting to learn how to differentiate typologies, varieties and different tastes of different types of olive oil. Therefore, the scope of this study is limited by this definition, understanding oleotourism as a wide concept.

Table I.

\begin{tabular}{lll}
\hline Pull factor & Kinds of activities & Name \\
\hline Experimental & $\begin{array}{l}\text { Olive picking, walk among the olive trees, visit to the } \\
\text { mill, tasting and purchase of the product }\end{array}$ & Oleotourism \\
Contact with nature & Natural environments, walking, hiking \\
Attractions & Zoos, safaris, wax museums, theme parks \\
Cultural heritage & Castles, palaces, museums, monumental sites, religious & Ecotourism \\
& places, archaeological sites & Interest tourism \\
Sport & Attending/participating in sports competitions \\
Entertainment & Cinema, theatre, bars, concerts, discos, restaurants \\
Relax & Resting, reading, sunbathing, going to the beach & Active tourism \\
Health and religion & Health treatments, saunas, massages, therapies & Leisure tourism \\
Shopping & Souvenirs, clothes, presents, equipment & Beach tourism \\
Business & Meetings, conferences, fairs & Health tourism \\
& & Shopping tourism \\
\end{tabular}

Source: Adapted from Ayuso and Fullana (2002) 


\section{Oleotourism and its potential}

Oleotourism implies complementarity with other types of tourism, and this product must be taken into account, not only because of its tangible part when the product is tasted but also because of the intangible benefits it has, such as its contribution to a healthier lifestyle and the connotations it has in other spheres of society (Ruiz, 2010).

This type of tourist offer is located in those places where olive trees are grown and olive oil is produced. This is why this product, because of its essential characteristics, is a seasonal one, as it is only harvested in a specific season, autumn/winter.

Having said this, we must bear in mind that, according to the definition of the oleotourist, they will value other aspects of the production process, such as the landscape. Olive trees are grown in 34 Spanish provinces, most of them in Andalusia and Castilla-La Mancha. The landscapes with olive trees contain great areas with olive trees with a traditional dryfarming growing. They also have a characteristic distribution and order. In the province of Jaén, they are called "seas of olive trees", as a way to introduce a very recognisable landscape (Díaz et al., 1997).

Alongside with the landscape, another attractive aspect is the Mediterranean cuisine culture, in which olive oil plays an essential role. This culinary tradition is gathering both national and international recognition (Kivela and Crotts; 2006; López and Sánchez, 2012), which has positioned olive oil above other vegetable fats. Nevertheless, we must keep in mind that, nowadays, olive oil consumption represents only 5 per cent of total of vegetable fats that are consumed worldwide (Mercacei, 2017). This shows that the potential of growth and introduction of olive oil is still very large.

Furthermore, it is important to highlight the industrial assets of the olive oil sector, the mills, the places where olives are processed after being harvested to become olive oil through a pressing process, filtering of solid particles and storage of the final product. This is a simple process which does not require a great amount of machinery. Facilities have been adapted to the new way of production, much more effective than the traditional one, from which there are still a great number of products that have been used until relatively recently, as a sample and representation of ethnographic heritage.

This new way, as can be checked with the description of the product itself, implies complementarity with other types of tourism, such as active tourism, culinary tourism and industrial tourism. This alone becomes a complement to agricultural economics in rural areas (Stewart et al., 2008; Millán and Agudo, 2010; Pagliuca and Scarpato, 2014).

Nevertheless, the focus of this study is to show the value of those intangible aspects which are characteristic of this agricultural practice and olive oil. Those characteristic aspects, such as singularity and durability, will contribute to a socio-economic and environmental development of destinations (Hjalager and Corigliano, 2000; Quan and Wang, 2004; Millán et al., 2015). Other types of tourism based on an agri-food product have developed widely both nationally and internationally in the tourist field. This is the case of the tourism of wine, enotourism (Stewart, 2008; Henderson, 2009; Cho et al., 2014; Corbo, 2014b; Millán et al., 2014; Medina, 2015). Its main difference may be that wine has become the tourist attraction itself and we could say that this tourist product is growing, whereas oleotourism is still an emerging product.

By contrast, olive oil is starting to be considered as a tourist resource according to different scholars (Martín, Molina and Ruiz, 2008; Moral and Orgaz, 2014; Moral et al., 2014; Hernández et al., 2016; Millán-Vázquez et al., 2017). 
All those forms of tourism can be put together as one and be called experimental tourism, which involves an added value for destinations (Hall and Weiler, 1992; Gandara, et al., 2012; Rivera, 2015) in view of the growth in demand of tourism with such a wide content (Tyrrell and Johnston, 2001; McKercher and Chan, 2005; Tyrrell and Johnston, 2006).

Oleotourism involves a number of principles for an enriching and sustainable kind of tourism because it is socially caring, economically viable and culturally rich (Lanfranchi et al., 2014; Galati et al., 2015; Schimmenti et al., 2016), which makes it a potential tourist attraction. From the point of view of the sustainability of the destination based on an agrifood industry, some scholars have described other aspects to keep in mind, such as (Corbo et al., 2014; Vecchio, 2014; Capri and Pomarici, 2014; Mariani and Vastola, 2015; Borsellino et al., 2016a, 2016b):

- resources efficiency;

- environmental preservation;

- local biodiversity conservation;

- investment in the quality of employees' work;

- cooperation with the local community;

- conservation and enhancement of traditions; and

- economic viability.

Moreover, the characteristics of enotourism customers and oleotourists who wish to learn more about olive oil have been compared (Ruiz, 2011; Millán, Arjona and Amador, 2014; Moral and Orgaz, 2014). Both share aspects, as they are both interested in two agri-food products and this sharing, therefore, could be understood as a tourist resource to face the growing demand of tourists that look for more experiences. The greater position and recognition that wine has for costumers contrast with olive oil consumption which is, as it has been previously stated, only 5 per cent of the total consumption of vegetable fats internationally (COI, 2017).

For oleotourism to succeed, the participation of the production sector is needed and, in this way, the revitalisation of the rural areas is promoted through tourist activity by using politics on the environment and on the rural area development (Molina and Ruiz, 2009; Molina et al., 2011; Moral, et al., 2014; Millán Vázquez de la Torre and Pérez, 2014; Millán, Amador and Arjona, 2015; Hernández et al., 2016; López-Guzmán et al., 2016).

\section{Methodology}

A questionnaire was designed and given to a group of olive oil consumers, who assessed several aspects of olive oil. A simple random sampling was used to select the sample, therefore obtaining a quantitative, exploratory and descriptive study.

The digital questionnaires were sent via email to an inter-university network of researchers on social and cooperative economy formed by 17 universities from Europe and Latin America. The participation in this network had an informal nature, as this study was not a part of their own research programmes. The researchers who were also university teachers extended it to their students too and questionnaires from 15 universities were received via email. Each responded questionnaire had a sequential numbering according to the order of arrival and, therefore, was treated anonymously. 
The sampling size was of 704 responded questionnaires, assuming a sampling error lower than 5 per cent. The participants come from 15 different universities. A translation into English was done as a common language for those universities which do not use Spanish as a working language. 55.8 per cent were women and the rest, 44.2 per cent, were men.

A Friedman non-parametric test was used for $k$ related samples $(k>2)$ in order to determine if significant differences existed between the respondents' assessments of the different fields. The null hypothesis $\left(H_{O}\right)$ establishes that no significant differences exist and the alternative hypothesis (H1) would indicate that significant differences do exist. To compare only two fields, the Wilcoxon test is used for two related samples.

Multidimensional scaling techniques were also used (multidimensional scaling, Kruskal and Wish, 1978) to interpret geometrically the proximity between the assessments of the different fields analysed.

\section{Assessment of olive oil as a tourist resource}

A data collection was carried out during the summer months thanks to a research funded by the Professorship in Cooperative Studies of the University of Castilla-La Mancha, through two methods: direct and indirect.

The greatest part of the total percentage (94.3 per cent of the sampling) was collected from people whose ages ranged between 17 and 44 years. The percentage of respondents aged between 45 and 60 years is practically insignificant, 3.9 per cent. The remaining 1.8 per cent is lost data which were not collected when the questionnaires were developed. As shown in Figure 1, the sampling is based on an important group of nationalities represented by percentages.

Participants were asked if they cooked regularly and the percentage of participants who responded positively was 73.6 per cent. Another point of interest was measuring the level of knowledge about different vegetable fats. Olive oil had the highest percentage of knowledge, 91.3 per cent.

Olive oil achieved the best knowledge ratios compared with other vegetable fats. Nevertheless, this percentage contrasts with its consumption and its impact on the

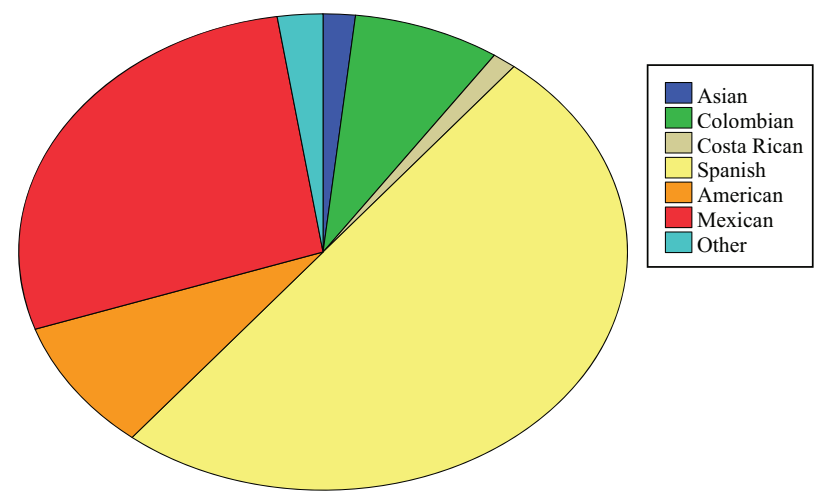

Source: Made by the author

Figure 1. Nationalities of the participants of the sampling 
vegetable fats market, which is only 4 per cent of global consumption (COI, 2017) Figure 2 .

In this research, the focus was to know the assessment the consumers did (from 1 to 10 , from less important to more important) about a series of intangible aspects of olive oil (Table II).

The collection of intangible aspects of olive oil (Ruiz, 2010) of different fields such as:

- culture;

- agriculture;

- health;

- environment;

- economy; and

- tourism.

Those aspects were selected based on a literature review that helped us identify nine aspects associated with oleotourism (Ruiz, 2010; Molina et al., 2011). This demonstrates that olive oil

Figure 2.

Types of olive oil known by people

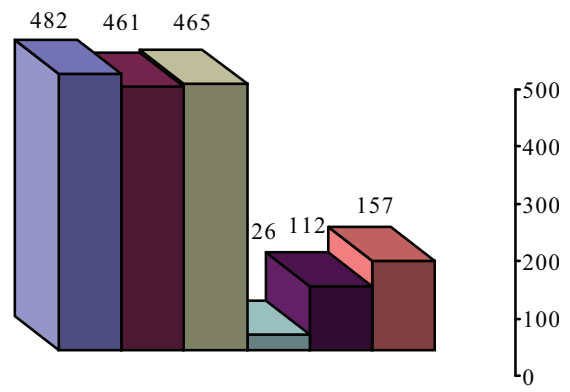

$\square$ Extra Virgin $\square$ Virgin $\square$ Olive $\square$ Lampante $\square$ Pomace $\square$ Refined

Source: Made by the author

Aspect

Nutrition (AL)

Cuisine (GS)

Health (SA)

Economy (EC)

Environment (MA)

Culture (CL)

Table II.

Results of the assessment of intangible aspects of olive oil
Tourism (TR)

History (HS)

Society (SC)

Religion (RG)

Source: Made by the author
Value 
played a role in each of the development stages of cultures and societies in the Mediterranean area.

These aspects were presented to the respondents for them to assess. They had to assign a quantitative value (from 1 , the lowest, to 10 , the highest value) to the extent to which, in their opinion, olive oil played a role in the fields of: nutrition, cuisine, health, economy, environment, culture, tourism, history, society and religion.

The first hypothesis, suggested that respondents' assessments would show that, according to them, olive oil is not related to tourism. Having achieved 4.9 points in the assessment showed clearly that consumers' opinion is different. This explains its boom as a tourist resource in recent years (Millán, Arjona and Amador, 2014).

H1. It is a fact that respondents recognise in their assessments that olive oil can have some tourist aspects.

Answer

Table III.

Rate of consumers asked about their interest in visiting the olive oil production process

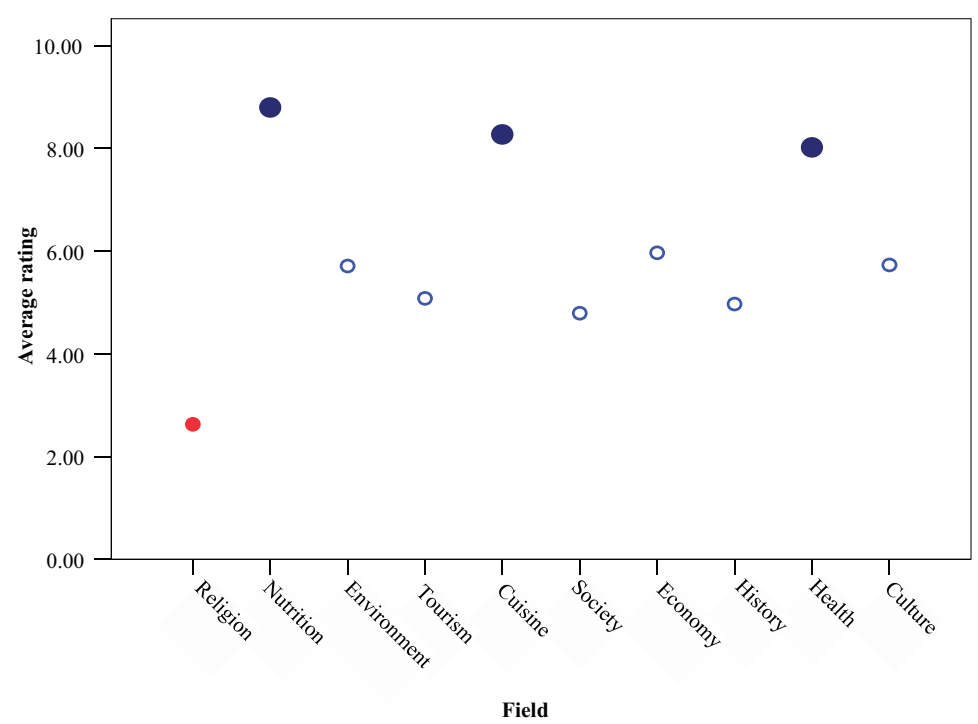

Source: Made by the author
Figure 3. Average rating of the assessment of intangible aspects of olive oil 
Consequently, they were asked how interested they would be in doing oleotourism. The results were enlightening, as more than 60 per cent of respondents stated that they would find travelling and learning about the olive oil production process interesting Table III.

The range of assessments made by the respondents can be seen in Figure 3. The difference in the religious aspect is quite noticeable, as it appears below the rest of assessments, with an average rating of 2.73 points.

To check if differences in opinions existed about the different aspects of olive oil assessed by the respondents, two hypotheses were considered. The null hypothesis $\left(H_{O}\right)$, which establishes that no differences in opinions exist, and the alternative hypothesis (H1) that establishes that differences do exist. Through a Friedman test we obtained the following Table IV.

As the $p$-value obtained is 0.000 , we must reject the null hypothesis, which shows there are differences between the different aspects analysed.

To check which aspects have those differences and which do not, we compared two to two every aspect. For that, we used a Wilcoxon test:

HO. No differences in opinions exist between the two aspects.

H1. Differences in opinions do exist.

Almost all the $p$-values obtained after the Wilcoxon test are 0.000 , so those results lower than 0.05 indicate significant differences in opinion. The aspects that obtained a $p$-value higher than 0.05 in the Wilcoxon test and therefore indicate that no significant differences exist are:

- $\quad$ economy and environment ( $p$-value $=0.099)$;

- culture and environment ( $\phi$-value $=0.622)$;

- $\quad$ history and tourism $(\phi$-value $=0.136)$; and

- history and society ( $p$-value $=0.103)$.

\section{The demand for oleotourism exists}

Now, following multidimensional scaling techniques, the distances between each of the aspects assessed by the respondents regarding the representativeness of olive oil are going to be established.

In this multidimensional scaling Chart (Figure 4), we can see that the most distant aspect (in a different colour) was Religion. The aspects Tourism and History were close to each other, and so was History in relation to Society, but Society and Tourism were more distant from each other. Thus, we can find a marked proximity between the aspects cuisine, nutrition and how these aspects, in the respondents' opinion, are essential for the health of olive oil consumers.

Table IV.

$$
N
$$

Chi-squared 


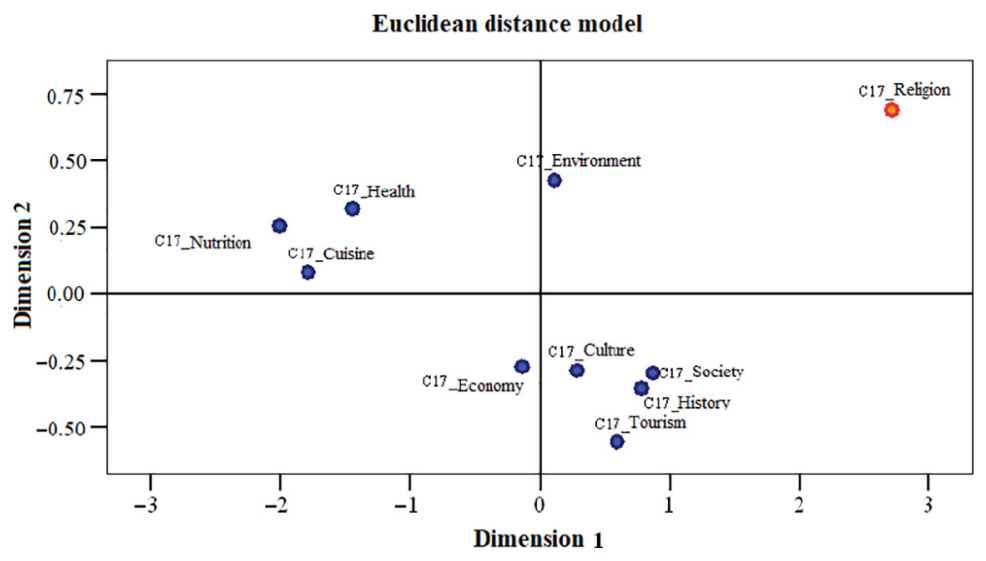

Source: Made by the author
Oleotourism

Figure 4.

Distances between the assessments of attraction of olive oil
As shown in Table $\mathrm{V}$, those aspects with a correlation coefficient close to 1 showed a greater similarity between them than those with a correlation coefficient closer to 0 , which showed less similarity.

In the light of the obtained results, we can state that the olive oil consumer demands a kind of tourism which includes activities that link oleotourism to the aspects of economy, culture and society of the destinations they intend to visit with the aim of investing time and money in learning about the olive oil production process.

\section{Conclusions}

The concept of oleotourism is now a new niche in the tourist sector because it has, according to the description in this study, a series of aspects that clearly separate it from other tourist fields.

This study shows that, to reinforce this new niche in the tourist market, the development of strategies is needed for the creation of tourist products with singularities, attractions and improvements in the on-line distribution.

\begin{tabular}{lllllllllll}
\hline & RG & AL & MA & TR & GS & SC & EC & HS & SL & CL \\
\hline RG & 1 & 0.056 & 0.207 & 0.125 & 0.027 & 0.234 & 0.106 & 0.303 & 0.124 & 0.235 \\
AL & 0.056 & 1 & 0.344 & 0.316 & 0.631 & 0.197 & 0.38 & 0.249 & 0.502 & 0.262 \\
MA & 0.207 & 0.344 & 1 & 0.485 & 0.307 & 0.459 & 0.441 & 0.395 & 0.412 & 0.45 \\
TR & 0.125 & 0.316 & 0.485 & 1 & 0.358 & 0.591 & 0.511 & 0.539 & 0.334 & 0.573 \\
GS & 0.027 & 0.631 & 0.307 & 0.358 & 1 & 0.273 & 0.399 & 0.266 & 0.499 & 0.257 \\
SC & 0.234 & 0.197 & 0.459 & 0.591 & 0.273 & 1 & 0.553 & 0.554 & 0.309 & 0.606 \\
EC & 0.106 & 0.38 & 0.441 & 0.511 & 0.399 & 0.553 & 1 & 0.55 & 0.426 & 0.515 \\
HS & 0.303 & 0.249 & 0.395 & 0.539 & 0.266 & 0.554 & 0.55 & 1 & 0.312 & 0.643 \\
SL & 0.124 & 0.502 & 0.412 & 0.334 & 0.499 & 0.309 & 0.426 & 0.312 & 1 & 0.388 \\
CL & 0.235 & 0.262 & 0.45 & 0.573 & 0.257 & 0.606 & 0.515 & 0.643 & 0.388 & 1
\end{tabular}

Source: Made by the author
Table V.

Similarities of intangible aspects of olive oil 
At the same time, a growing demand has appeared because of the tourists' interest in doing experimental tourism, which enables them to learn more about a product with some intangible aspects that can be measured according to the consumers' assessment.

We can say, after having reviewed the concepts used by the mentioned researchers, that oleotourism is a type of tourism by itself, and that its main characteristic entails living experiences linked to the olive tree culture, its environment and the food culture based on it.

There are different activities with an important development potential. In this study we have proved that more than 60 per cent of respondents stated that they would be interested in travelling to areas with olive oil production and in learning about the role of this product in its environment through its production process.

Tourism based on agri-food products implies reinforcing historic and cultural tourism, as the results of this study show. Furthermore, it helps boost cohesive development in rural areas to create new tourist attractions to add value to the area.

One example is the development of tourist products that complement each other and other types of tourism and that, for reasons of proximity, complementarity or need, share "ancestral" characteristics with the historic and artistic heritage of the production areas. The representation of customers' assessments leads us to think about the possibility of creating planning and development strategies in those tourist destinations where olive trees are grown and olive oil is produced. This would increase the number of tourists in these rural areas and this would create more marketing possibilities for the products that they produce.

Oleotourism is now a new concept that helps reinforce other tourist fields that, through this study, have been linked through a quantitative assessment. In this way, we can state that rural tourism, agrotourism and health are elements that have some complementarity and proximity so as to be exploited jointly.

From this study, we learn that all the agents with decision-making capacity in tourist politics should include oleotourism as a new paradigm that can offer new experiences to the tourists with new demands. Therefore, products and services derived from it should be included in the tourist offer of other types of tourism, such as rural tourism, agrotourism, cultural tourism, as this would create synergies that would enable economies of scale for the rural tourist sector.

The creation of a tourist product based on pull factors from a destination with olive oil production can lead to a number of opportunities for those destinations. This study focuses on the search, from the demand point of view, for answers about the possible intention to pay for visiting and learning about the olive oil production process. In the future, in a few years, we hope a correlation study is possible in order to check if, as this study shows, oleotourism helps, during its marked seasonal period in these areas, to improve the quality of life of the inhabitants of those destinations. Another opportunity ahead is to check if it complements the sustainability of the rural destinations with production and if it boosts these places socio-economically, not only in Spain but also in those places where olive oil is produced.

\section{References}

Ayuso, S. and Fullana, P. (2002), Turismo Sostenible, Ed. Rubes, Barcelona.

Bacq, S. and Janssen, F. (2011), "The multiple faces of social entrepreneurship: a review of definitional issues based on geographical and thematic criteria”, Entrep. Reg. Dev, Vol. 23 Nos 5/6, pp. 373-403. 
Borsellino, V., Migliore, G., D’acquisto, M., Di Franco, C.P., Asciuto, A. and Schimmenti, E. (2016a), "Green' wine through a responsible and efficient production: a case study of a sustainable sicilian wine producer", Agric. Agric. Sci. Proc, Vol. 8, pp. 186-192.

Borsellino, V., Pisano, G., Ievoli, C. and Schimmenti, E. (2016b), "Is green harvesting a useful instrument to solve market problems in the wine sector? Some lessons from sicily", Qual. - Access Success, Vol. 17 No. 151, pp. 78-84.

Capri, E. and Pomarici, E. (2014), "Modelli di sostenibilità a confronto nel settore vitivinicolo italiano", Il Corriere Vinic, Vol. 9, pp. 16-17.

Caracciolo, F., Cicia, G., Del Giudice, T., Cembalo, L., Krystallis, A., Grunert, K.G. and Lombardi, P. (2016), "Human values and preferences for cleaner livestock production", J. Clean. Prod, Vol. 112, pp. 121-130.

Cembalo, L., Caracciolo, F., Lombardi, A., D., Giudice, T., Grunert, K.G. and Cicia, G. (2016), "Determinants of individual attitudes toward animal welfare-friendly food products", J. Agric. Environ. Ethic, pp. 1-18.

Cho, M., Bonn, M.A. and Brymer, R.A. (2014), "A constraint-based approach to wine tourism market segmentation", Journal of Hospitality and Tourism Research, Vol. 38 No. 2, pp. 1-30.

Consejo Oleícola Internacional - COI (2017), "Consumo internacional de grasas vegetales", Revista Olivae, Num, Vol. 123.

Corbo, C., Lamastra, L. and Capri, E. (2014), "From environmental to sustainability programs: a review of sustainability initiatives in the italian wine sector", Sustainability, Vol. 6 No. 4, pp. 2133-2159.

Corbo, C., Sogari, G., Macconi, M., Menozzi, D. and Mora, C. (2014b), "Vino sostenibile: l'atteggiamento dei consumatori italiani”, Agriregionieuropa, Vol. 10 No. 39.

Díaz, M., Campos, P. and Pulido, F.J. (1997), "The Spanish dehesa: a diversity in land use and wildlife", in Pain, D. and Pienkowsky, M. (Eds), Farming and birds in Europe: the common agricutural policy and its implications of bird conservation, Academic Press, London, pp. 178-209.

Dodds, R., Graci, S.R. and Holmes, M. (2010), "Does the tourist care? A comparison of tourists in Koh Phi Phi, Thailand and Gili Trawangan, Indonesia”, Journal of Sustainable Tourism, Vol. 18 No. 2, pp. 207-222.

Galati, A., Borsellino, V., Crescimanno, M., Pisano, G. and Schimmenti, E. (2015), "Implementation of green harvesting in the sicilian wine industry: effects on the cooperative system", Wine Econ. Policy, Vol. 4 No. 1, pp. 45-52.

Gandara, J.M., Mendes, J. and Moital, M. (2012), "Planificación estratégica de un circuito turístico histórico-cultural experiencial: Itabuna-Bahia, Brasil”, en Estudios y Perspectivas en Turismo, Vol. $21 n$ No. 1, pp. 225-248.

Hall, C.M., Weiler, B. (Eds), (1992), Special Interest Tourism, Introduction, Wiley, New York, NY, pp. 1-14.

Henderson, J.C. (2009), "Food tourism reviewed”, British Food Journal, Vol. 111 No. 4, pp. 317-326.

Hernández, J.M., Folgado, J.A. and Campón, A.M. (2016), "Oleoturismo en la sierra de gata y las hurdes (Cáceres): análisis de su potencial a través de un test de producto", International Journal of Scientific Management and Tourism, Vol. 2 No. 1, pp. 333-354.

Hjalager, A. and Corigliano, M. (2000), "Food for tourists, determinants of an image", International Journal of Tourism Research, Vol. 2 No. 4, pp. 281-293.

Instituto Nacional de Estadítica (INE) (2009), Censo Agrario.

Kivela, J. and Crotts, J. (2006), "Tourism and gastronomy: gastronomy"s influence on how tourists experience a destination", Journal of Hospitality and Tourism Research, Vol. 30 No. 3, pp. 354-377.

Kruskal, J.B. and Wish, M. (1978), Multidimensional Scaling, SAGE.

Lanfranchi, M., Giannetto, C., Zirilli, A. and Alibrandi, A. (2014), "Analysis of the demand of wine in sicily through ordinal logistic regression model”, Qual. Access Success, Vol. 15 No. 139, pp. 87-90. 
Lombardi, A., Migliore, G., Verneau, F., Schifani, G. and Cembalo, L. (2015), “Are 'good guys' more likely to participate in local agriculture?”, Food Qual. Prefer, Vol. 45, pp. 158-165.

López-Guzmán, T., Cañero, P.M., Moral, S. and Orgaz-Agüera, F. (2016), “An exploratory study of olive tourismconsumers”, Tourism and Hospitality Management, Vol. 22 No. 1, pp. 57-68.

López-Guzmán, T. and Sánchez Cañizares, S. (2012), "La gastronomía como motivación para viajar. Un estudio sobre el turismo culinario en córdoba", Pasos Revista de Turismo y Patrimonio Cultural, Vol. 10 No. 5, pp. 575-584.

Mariani, A. and Vastola, A. (2015), "Sustainable winegrowing: current perspectives", Int. J. Wine Res, Vol. 7, pp. 37-48.

Martha, L. and Kotsaki, A. (2013), "Ancient greek drama and its architecture as a means to reinforce tourism in Greece", Procedia, Vol. 148, pp. 573-578.

Martha, L. and Kotsaki, A. (2015), "The museum culture as a means of conjunction of the urban and rural environment", Procedia, Vol. 145 No. 2015, pp. 601-606.

Martín, V., Molina, V. and Ruiz, I. (2008), "Diversificación de la economía social Para subsistir en el siglo XXI. Turismo cooperativo potencial en Castilla-La Mancha”, Actas Coloquio Ibérico de Estudios Rurales: Cultura, Innovación y Territorio. 2008, Coimbra, Portugal.

Mckercher, B. and Chan, A. (2005), "How special is special interest tourism?", Journal of Travel Research, Vol. 44 No. 1, pp. 21-31.

Medina, F.X. (2015), “Turismo Y cultura En denominaciones De origen enogastronómicas: el caso de la región De Tokaj-Hegyalja (hungría"). International Journal of Scientific Management and Tourism, Vol. 1 No. 3, pp. 167-178.

MERCACEI (2017), "El consumo mundial de aceite de oliva según el COI”, 12 de diciembre de 2017, available at: www.mercacei.com/noticia/48113/actualidad/el-consumo-mundial-de-aceite-deoliva-aumentara-un-5-en-la-campana-2017/18-segun-el-coi.html

Migliore, G., Caracciolo, F., Lombardi, A., Schifani, G. and Cembalo, L. (2014), "Farmers' participation in civic agriculture: the effect of social embeddedness. Cult., agric", Culture, Agriculture, Food and Environment, Vol. 36 No. 2, pp. 105-117.

Migliore, G., D., Gesaro, M., Borsellino, V., Asciuto, A. and Schimmenti, E. (2015), "Understanding consumer demand for sustainable beef production in rural communities", Qual. - Access Success, Vol. 16 No. 147, pp. 75-79.

Millán Vázquez De La Torre, G. and Agudo Gutiérrez, E. (2010), "El turismo gastronómico y las denominaciones de origen en el sur de españa: Oleoturismo. Un estudio de caso", Pasos Revista de Turismo y Patrimonio Cultural, Vol. 8 No. 1, pp. 91-112.

Millán Vázquez de la Torre, M.G. and Pérez, L.M. (2014), "Comparación del perfil de enoturistas y oleoturistas en España: Un estudio de caso", International Journal of Rural Development, ISSN-e: 0122-1450, Vol. 11 No. 74, pp. 167-167.

Millán, G., Amador, L. and Arjona, J.M. (2015), "El oleoturismo: una alternativa para preservar los paisajes del olivar y promover el desarrollo rural y regional de andalucía (españa)", Revista de Geografia Norte Grande, Vol. 60, pp. 195-214.

Millán, G., Arjona, J.M. and Amador, L. (2014), “A new market segment for olive oil: olive oil tourism in the South of Spain”, Agricultural Sciences, Vol. 05 No. 3, pp. 179-185.

Millán-Vázquez, M.G., Arjona, J.M. and Amador, L. (2017), "Olive oil tourism: promoting rural development in andalusia (Spain)”, Tourism Management Perspectives, Vol. 21 No. 2017, pp. 100-108.

Molina, M.V. and Ruiz, G.I. (2009), Diversificación de la Economía Social Para Subsistir en el Siglo XXI. Turismo Cooperative Potencial en Castilla-La Mancha, en Actas Coloquio Ibérico de Estudios Rurales, Cutura, Innovación y Territorio, Coimbra, Portugal.

Molina, V., Quesada, J.M. and Ruiz, I. (2011), "Potencial del oleoturismo como diversificación económica del sector cooperativo agrario: el caso español”, Revista de Ciencias Sociales, Vol. 17 No. 3, pp. 533-541. 
Moral, S., Cañero, P.M., Orgaz, F. and López-Guzmán, T. (2014), "Una aproximación al oleoturismo en andalucía, españa”, International Journal of World of Tourism, Vol. 1 No. 2.

Moral, S. and Orgaz, F. (2014), "The typologies of tourism in Cordoba (Spain): a review of the scientific literature resumen”, Gran Tour: Revista de Investigaciones Turisticas, Vol. 9, pp. 112-133.

Pagliuca, M.M. and Scarpato, D. (2014), "The olive oil sector: a comparison between consumers and 'experts' choices by sensory analysis", Procedia Economics and Finance, Vol. 17, pp. 221-230.

Parrish, B.D. (2010), "Sustainability - driven entrepreneurship: principles of organization design", Ournal of Business Venturing, Vol. 25 No. 5, pp. 510 -523.

Quan, S. and Wang, N. (2004), "Towards a structural model of the tourist experience: an illustration from food experiences in tourism”, Tourism Management, Vol. 25 No. 3, pp. 297-305.

Rivera, M. (2015), “Turismo experiencial y gestión estratégica de recursos patrimoniales: un estudio exploratorio de percepción de productos turísticos en las sierras subbéticas cordobesas (Andalucía)", Scripta Nova: Revista Electrónica de Geografia y Ciencias Sociales, Vol. 19 No. 511, pp. 1-34.

Ruiz, I. (2010), Análisis Cuantitativo y Cualitativo de Los Intangibles Del Aceite de Oliva. Una Aproximación Desde el Punto de Vista Del Consumidor, Universidad de Granada. Granada.

Ruiz, I. (2011), “Olive oil as a tourist resource: conceptual boundaries”, Olivae, Vol. 115, pp. 32-47.

Ruiz, I., Molina, V. and Martin, V. (2011), "El oleoturismo como atractivo turístico en el medio rural español”, Papers de Turisme, Vols 49/50, pp. 89-103.

Schimmenti, E., Daddi, G., Asciuto, A., Borsellino, A., D., Franco, C.P. and Di Gesaro, M. (2016), "Agriculture in a sicilian inland area: strategies and motivations of conversion towards multifunctional activities qual”, Access Success, Vol. 17 No. 150, pp. 87-92.

Stewart, J.W., Bramble, L. and Ziraldo, D. (2008), "Key challenges in wine and culinary tourism with practical recommendations", International Journal of Contemporary Hospitality Management, Vol. 20 No. 3, pp. 302-312.

Tilley, F. and Young, W. (2009), "Sustainability entrepeneurs-could they be the true wealth generators of the future?", Greener Management International, Vol. 55, pp. 79-92.

Turespaña, (2014), Memoria Annual 2014, Instituto de Turismo de España. Madrid.

Tyrrell, T.J. and Johnston, R.J. (2001), "A theoretical framework for assessing direct economic impacts of tourist events; Distinguising origins, destinations and causes of expenditures", Journal of Travel Research, Vol. 40 No. 1, pp. 94-101.

Tyrrell, T.J. and Johnston, R.J. (2006), "The economic impacts of tourism: a special issue”, Journal of Travel Research, Vol. 45 No. 1, pp. 3-7.

UNWTO (2017a), "World tourism barometer", Advance release January 2017, Vol. 15, available at: http://mkt.unwto.org/es/publication/panorama-omt-del-turismo-internacional-edicion-2016

UNWTO (2017b), “Tourism highlights”, 2017 Edition, available at: www.e-unwto.org/doi/pdf/10.18111/ 9789284419029

Vecchio, R. (2014), "Economic impact of sustainable vitiviniculture best practices".

\section{Further reading}

Aybar, R. (2004), "Proyecto oleoturismo: Una red europea Para la promoción de la cultura del olivo. Diputación provincial de jaén”, Documento CULT-04.

Folgado-Fernández, J.A., Ramiro, P., Campón-Cerro, A.M. and Hernández Mogollón, J.M. (2017), "Productos gastronómicos con identidad y desarrollo del destino turístico. Un estudio sobre rutas del queso en españa”, International Journal of Scientific Management and Tourism, Vol. 3 No. 1, pp. 93-109. 
INEA (2015), “Annuario dell'agricoltura italiana 2014”, Marchesi Grafiche Editoriali S.p.A., Roma. Instituto de Turismo de España (2014), Plan Integral de Turismo Rural, TURESPAÑA.

López, Y., Montes, F. and Moreno, A. (2013), Patrimonio Industrial Oleicola, ACUVIS, Córdoba.

López-Guzmán, T., Rodríguez-Garcia, J., Sánchez-Cañizares, S. and Luján-García, M.J. (2011), “The development of wine tourism in Spain”, International Journal of Wine Business Research, Vol. 23 No. 4, pp. 374-386.

Millán, G., Pérez, L. and Martínez, R. (2016), "Factores que determinan el crecimiento del turismo en destinos religiosos", Revista de Ciencias Sociales, Vol. XXII, pp. 85-97.

Ministry of Agriculture and Environment MAGRAMA (2015), "Denominaciones de origen e indicaciones geográficas protegidas", available at: www.magrama.gob.es

UNWTO (2016), Panorama OMTE Del Turismo Internacional, edición 2016. Organización Mundial de Turismo. Madrid.

\section{Corresponding author}

Ignacio Ruiz Guerra can be contacted at: ignacio.ruiz@ucm.es

For instructions on how to order reprints of this article, please visit our website: 